\title{
Law Enforcement Agencies in Disaster Response in Nepal: Analyzing the Competency of the Nepal Police and the Armed Police Force
}

\author{
Malla S. B. ${ }^{1}$, Dahal R. K. ${ }^{2} \&$ Hasegawa S. ${ }^{3}$ \\ ${ }^{1}$ Faculty of Engineering, Kagawa University, Takamatsu, Japan \\ ${ }^{2}$ Central Department of Geology, Tribhuvan University, Kritipur, Nepal \\ ${ }^{3}$ Faculty of Engineering, Kagawa University, Takamatsu, Japan \\ Correspondence: Shrijan Bahadur Malla, Faculty of Engineering, Graduate School of Engineering, Kagawa \\ University, 2217-20 Hayashi-cho, Takamatsu, Kagawa 761-0396, Japan. Tel: 977-986-133-4004. E-mail: \\ shrijan7malla@hotmail.com
}

Received: October 20, 2020 Accepted: December 26, 2020 Online Published: January 10, 2021

\begin{abstract}
Although Nepal Police and Armed Police Force are the key responding tools of disaster response in Nepal, their response competency does not suffice the need for effective response. Applying quantitative research methodology, this research has in-depth investigated the fundamental and technical knowledge, and preparedness activities of such police personnel. Ultimately it was discovered that their knowledge and preparedness are not adequate to meet the need. On the other hand, the practice of the usage of disaster untrained police personnel in response operations is prevalent in the country. And this tendency is not only risking the life of the disaster victims but also putting the responders' lives at stake. Amidst such bleakness, during the investigation, the perception of the police personnel on their engagement in disaster response was found highly aspiring. Indeed this tendency will work as the force multiplier if their capacity is enhanced properly. The study has further investigated that the lethargic national investment in the disaster response capacity building process is the fundamental problem in terms of the competency building process. Heavy reliance on foreign aids and national and international non-government agencies has not only increased the dependency on capacity building process but also mired the national mechanism turning responsible authorities and institutions lethargic.
\end{abstract}

Keywords: Nepal Police, Armed Police Force, competency, knowledge, preparedness, perception

\section{Introduction}

In Nepal, Nepal Police (NP) and Armed Police Force (APF) are two police organizations mandated to function for disaster response in addition to their law and order maintenance responsibility in the country. Today directed by Disaster Reduction and Management Act 2017, these two organizations are the vital organs of disaster response system of the country (Disaster Risk Reduction and Management Act 2017, 2017).

In worldly context, by the virtue of the responsibility of maintaining public order and safety, police forces, irrespective of their capabilities are always the government's first responder and function as the frontline agency during disaster (Quartelli \& Dynes, 1977; Drabek, 1985). Towyn flood 1990, Indian Ocean Tsunami 2004, Hurricane Katrina 2005 and Japan's earthquake and tsunami 2011 are some disasters where the police forces were significantly used for response operations (Pine, 1996; Anderson, 2006; Bird et al., 2007; Yasuda \& Soma et al., 2014).

Police forces' disaster response can be categories in two categories. First, response through normal policing duties such as aiding citizens, collection and relying information, traffic control, crowd control, evacuation of people from disaster sites, etc (Bonkiewicz \& Ruback, 2012). Second generic policing duty converges into disaster response operations such as management of command post, search and rescue, evacuations of victims, medical assistance, management and distribution of relief materials, establishment of temporary shelter for victim, etc (Varano \& Schafer, 2012). And Nepal falls into the second category where NP and APF are comprehensive engaged in disaster response.

Nepal is amongst the most disaster prone countries in the world where over $80 \%$ of the population lives at risk of disasters such as flood and inundation, landslide, inferno, avalanche, thunderstorm, glacial lake outburst (MoHA $\&$ DP Net-Nepal, 2015). Every year more around 400 people die due to such disaster consequences in the country. 
Despite this bleakness, the country doesn't possess an effective response mechanism and heavily reliant on the security forces.

The institutional history of systematic disaster response of NP and APF is not too long (Nepal Police, 2016). It's been few years that the disaster management divisions were established in these two organizations. Primarily two circumstances played critical role for this transformation. First was the Nepal's participation in international conference of Hyogo Framework for Action (18-22 January 2005). The conference delivered a message to the world that 'disaster' is a global agenda that needs state's every component to get involved into dealing with (Zhou et al., 2014). And second was the 2012 Gorkha Earthquake where 8970 people got killed (MoHA, 2016). These two events delivered a sense of realization amongst the political leaderships that the 'establishment of technical search and rescue' is imperative for effective response and that should begin from materializing the concept in security forces.

Today both the police organizations have Disaster Management Division in their institutions. The APF have incorporated the 'disaster management role' in its act as well (Subedi, 2013). Besides, the organization has Disaster Management Training Center, Disaster Response Battalion, and disaster response bases in three different parts of the country (Subedi, 2013). Similarly, NP is also in the verge of establishing the 'disaster response unit' at each provincial headquarters and its Disaster Management Division is busy to generate competent human resource for such units.

From the capacity aspect, in disaster response, the troops of security forces of developing countries can be divided into two categories. The specialized troops, that are in limited strength and centralized and the ordinary troops, that are larger in strength, ubiquitously deployed and immediately mobilized at a local level when disaster occurs.

During response, the specialized troops are always the second echelon that takes time for deployment, whereas time factor is very crucial at that moment. Research has proven that $80 \%$ of life can be saved if rescued within first few hours of disaster (Tanaka, 1996). In that sense, locally deployed ordinary troops are always the critical assets and are the fundamental pillar of the local level disaster response mechanism. But 'how to maintain their disaster response competency' is always a questionable issue in broader aspect (Grunewald \& Burlet, 2016).

Various researches have proven that the knowledge, preparedness and perception are three interlinked core values of the disaster response competency. Knowledge increases the awareness of action to be taken and increases the efficiency of doing things therefore is a force-multiplier (Mendis et al., 2007). Barelli et al. have stated that a disaster responder requires two categories of knowledge - 'Soft Skill Knowledge (SSK)' and 'Technical Skill Knowledge (TSK)' (Barelli et al., 2014). SSK is fundamental non-technical, interpersonal and cognitive such as principles, leadership, teamwork, and communication, etc whereas the TSK is procedural and systematic that is required to function the technical work such as search and rescue, debris management, dead body management, casualty evacuation, etc (Poul, 2019).

Whereas preparedness increases confidence, efficiency and reduce duplication of effort thus saves time and increases overall effectiveness of a response. Gillespie and Colingnon claimed that the preparedness can be achieved from a process of proper planning, training, exercise and rehearsal that ultimately reduces the mortality and morbidity, and prevent the loss of property (Gillespie \& Colignon, 1993). Drabek and Hoetmer also stated that the preparedness is vital for competency building process since it helps to determine responsibility, identify function and resource, and increases inter-organizational coordination and communication that are the typical problems especially in developing countries at the time of disaster response (Drabek \& Hoetmer, 1991; Heide, 1989).

Efron, and Knoblich and Sebanz have asserted that the perception is a sense of realization that shapes the conceptual knowledge and primary form of awareness (Efron, 1969; Knoblich \& Sebanz, 2006). It influences the responder's willingness to engage in disaster response (Penrose, 2000) thus is also a factor of force multiplier. Wolf and Moser argued that since perception is a view and interpretation based on belief, experience and understanding can help to examine the response competency of a responder (Wolf \& Moser, 2011).

Twigg and Mosel explained that the responder without fundamental knowledge, preparedness and perception doesn't only pose a problem to a response operation but also puts victims' lives and own life at risk (Twigg \& Mosel, 2017). Thus to maintain the police personnel's disaster response capability the competency building curriculum such as training, exercise, and rehearsal is imperative prior to their engagement (Descy \& Tessaring, 2002; Ingrasssia, 2014). In this back drop, this paper has investigated the disaster response competency of the ordinary troops of NP and APF deployed at local level in the country. Whether they can respond effectively or not during disaster is the crux of the findings of this investigation. 


\section{Methodology}

\subsection{Research Overview}

Although mixed (quantitative and qualitative) methodology has been adopted during investigation moreover findings are based on quantitative research. From first hand data collection and analysis to the review of various disaster literatures and interview with disaster experts have been the processes followed during research. Primarily three components of competency-fundamental knowledge, preparedness and perception-were investigated thoroughly. Along with investigating the disaster response competency of police personnel this study has also underscored the overlooked factor of the disaster response competency building process in the police organizations.

\subsection{Sample Population}

Altogether, as study participant, 246 police personnel were randomly selected from twelve central districts of the country (see figure 1). Since mid hill and terai are the most disaster prone regions of Nepal five hilly districts and seven terai districts were chose for the data survey (Chhetri, 1999). Amongst study participants 128 were taken from NP and 118 were taken from APF. And their service period spanned from 3 years to 29 years, with the mean value of 13.68 years and the standard deviation (SD) is 6.009 .

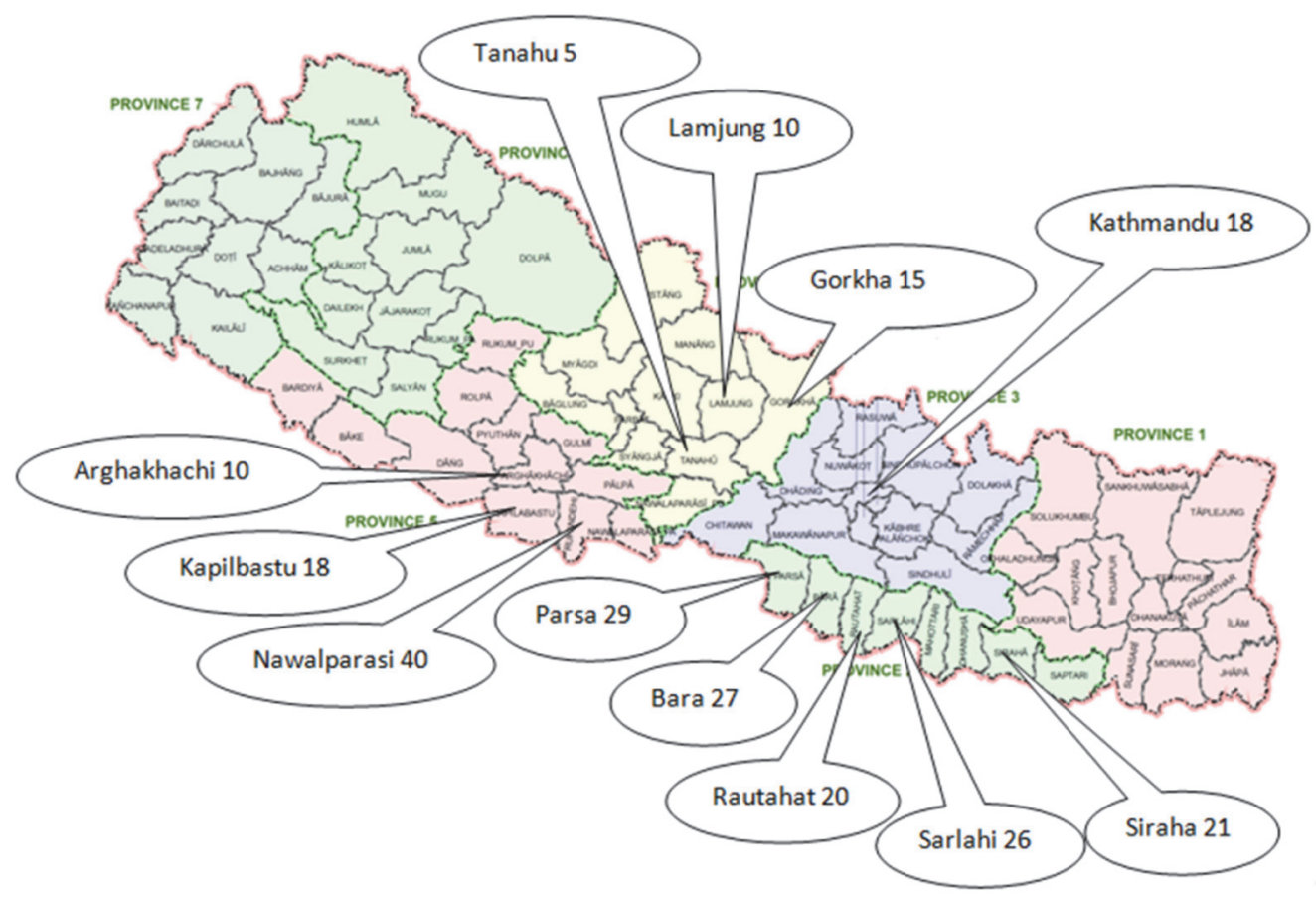

Figure 1. Study participants as per district.

\subsection{Research Design}

Altogether 23 closed-ended Self Administered Questions (SAQ) that were classified into three categories, were asked to the participants (Brancato et al., 2004; Ronan et al., 2010; Kuroiwa, 1993; Arya, 1993). The first category was about the fundamental and technical knowledge, that comprised of fifteen questions. Investigating 'how knowledgeable are the study participants in disaster response issues ' has been the objective of these questions. Three questions were asked in second category to investigate their level of disaster response preparedness. And at the end, in third category, five questions were asked to identify the study participants' perception on the police personnel's disaster response engagement.

All the questionnaires were designed closed-ended 'choose the best' type and were re-coded as an ordinal scale during analysis. For the ease of understanding for study participants the questions were prepared in Nepali script and subsequently during analysis they were translated into the English literature. Enumerators that are experienced in disaster management venture were employed to assist the participants during questionnaire survey. The survey was conducted in an interview style and took 20-30 minutes to each participant to complete the whole process. 


\subsection{Method of Analysis}

Based on inferential analysis method three key independent variables- disaster knowledge, perception, and preparedness -and two dependent variables- NP and APF - were analyzed during the research. Cross Tabulation tool was adopted to investigate the relation between dependent and independent variables. Similarly Linear Regression and Bivariate Correlation test was applied to investigate the statistically significant. The results were illustrated in bar-diagrams, pie charts and tables. The SPSS 16.0 software was utilized during the overall process of analysis.

\section{Result and Analysis}

\subsection{Disaster Management Knowledge}

\subsubsection{Fundamental Knowledge}

Eight questions were asked to investigate the fundamental disaster management knowledge of the participants and the result illustrated that the understanding was pity especially in six issues. When asked about the phases of disaster management cycle, only $18 \%$ of the participants replied that it has four phases. About the engagement of security forces in disaster management process only less than $40 \%$ of the respondents replied that the forces are the primary tool for the Search and Rescue operation. Rest $60 \%$ believed that security forces have comprehensive engagement throughout the disaster management cycle which is indeed incorrect. Similarly, only $25 \%$ of the participants believed that the local community is the first responder once disaster occurs. Other believed that it is the security forces that respond immediately at the onset of a disaster.

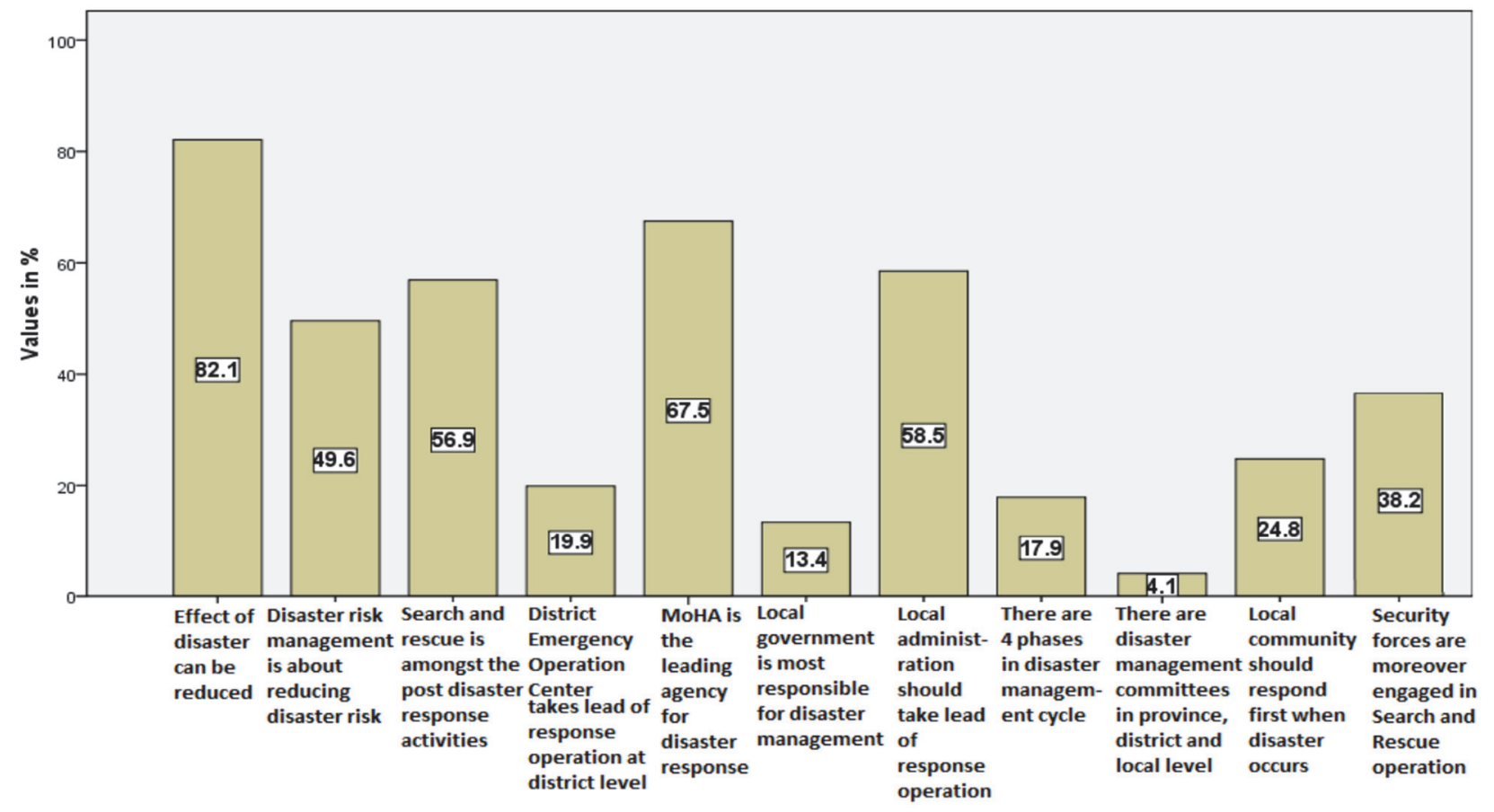

Figure 2. Fundamental disaster management knowledge

Likewise, $67 \%$ of the participants were found familiar with the fact that the Ministry of Home Affairs (MoHA) is the focal ministry for disaster response. Another $58 \%$ were found having well understanding of the role of the Chief District Officer (CDO) during response. They agreed that the CDO should lead the disaster response operation at district level. But dismayingly, $80 \%$ of the participants were not found aware of the role of the District Emergency Operation Center (DEOC). They didn't know that the DEOC should function as the Command Post at district level to control the response operation during disaster.

Similarly, only $13 \%$ of the participants replied that the local government is the most responsible tier of the government to conduct effective response in the country. Rests of the participants have preconception that the central government is the most responsible entity for the purpose. Unfortunately only $4 \%$ of the participants have 
knowledge that there are disaster management committees at province, district and local level in Nepal. Others were found indifference about these structures.

Indeed, such dearth of fundamental knowledge doesn't warrant the acquaintance of the responders in the national disaster response mechanism and the system. They are pretty confused on the structures, command mechanism and the roles of various entities. Such confusions are counterproductive to maintain their disaster response competency (see figure 2).

\subsubsection{Technical Disaster Response Knowledge}

The technical knowledge of the participants was also found low. Among seven questions asked only in two questions the responses were found above average (see figure 3). Nearly $60 \%$ of the participants were unaware of the protocol to be carried out during search and rescue of a collapsed house. Similarly, only $31 \%$ correctly replied that foam type fire extinguisher is used for diesel and kerosene fire. $69 \%$ of the participants were confused about the type of fire extinguisher and their purpose. Another $63 \%$ participants didn't have an idea about how to manage the parts of dead body recovered from disaster site. Around $61 \%$ of the participants were also unaware of the issue that prior rescuing a trapped person from under a concrete slab the oxygen and water should be provided to him to recuperate his life. And unfortunately $85 \%$ of the participants didn't know that before entering a disaster incident site for search and rescue operation one should acquire the detail information from various sources. Indeed such lack of technical knowledge proves that the participants are not technically sound in response operations.

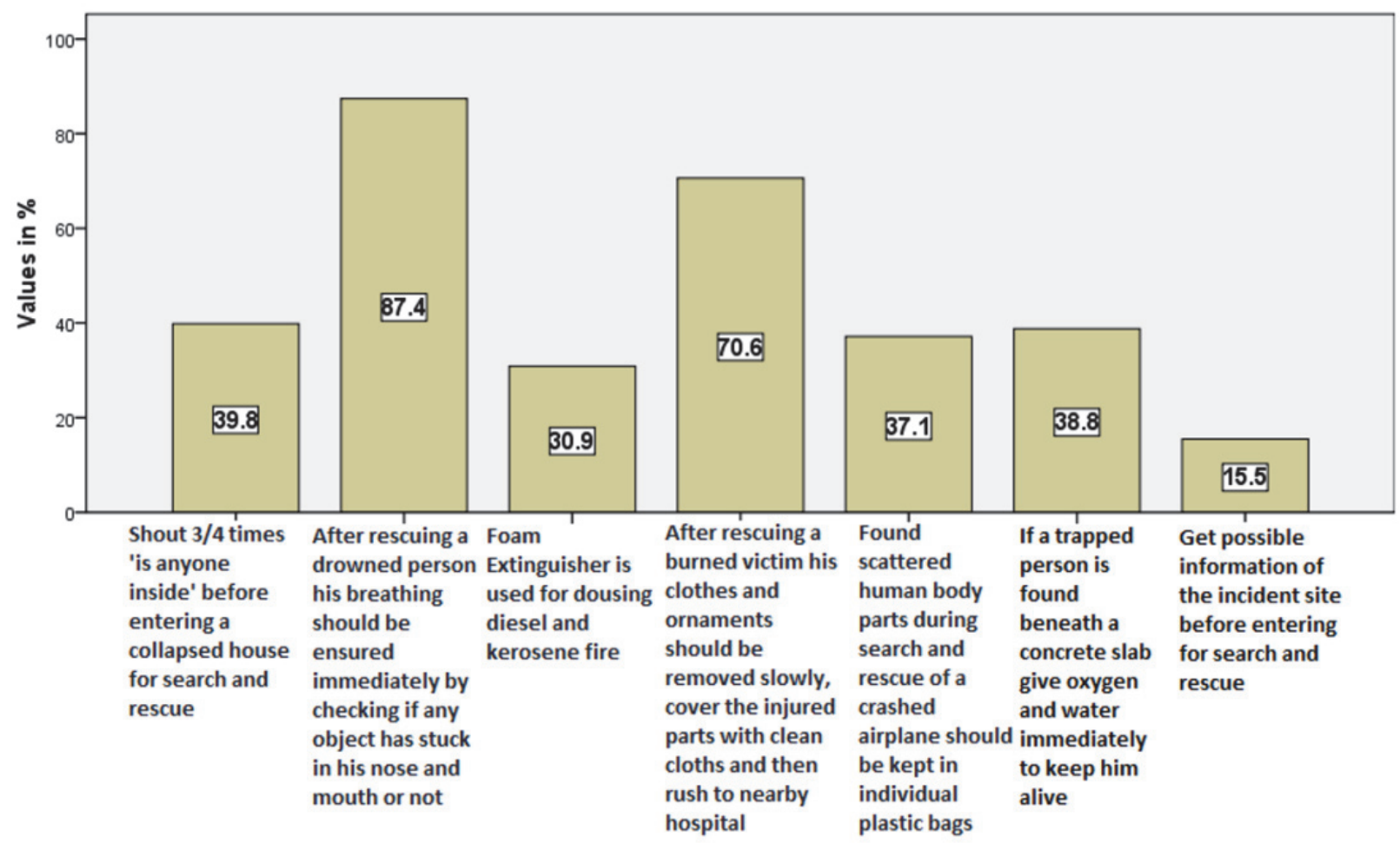

Figure 3. Technical disaster response knowledge

Only in the questions of the 'burn case' and 'drawn case' the responses were found above average. $87 \%$ of the participants were aware of the issue that the breathing of a drowned victim should be checked immediately once he is rescued from the water and $70.6 \%$ of the participants had knowledge that the cloths and ornaments of a burned victim should be removed slowly prior to rushing him to the nearby hospital. 


\subsection{Perception of Disaster Response Engagement}

Among five questions asked to the participants in four questions their responses were found above average which is encouraging (see figure 4). Over $85 \%$ of the participants agreed that the disaster response engagement of the police force is rational in today's context and that is helping them to enhance their professionalism as well. Similarly, $93 \%$ of the participants agreed that their disaster response engagement should be increased in the future and $61 \%$ of the participants replied that their disaster response engagement should be made more effective in the upcoming days. Only $62 \%$ of the participants failed to comprehend that the disaster response engagement helps them to win the heart and mind of the local population.

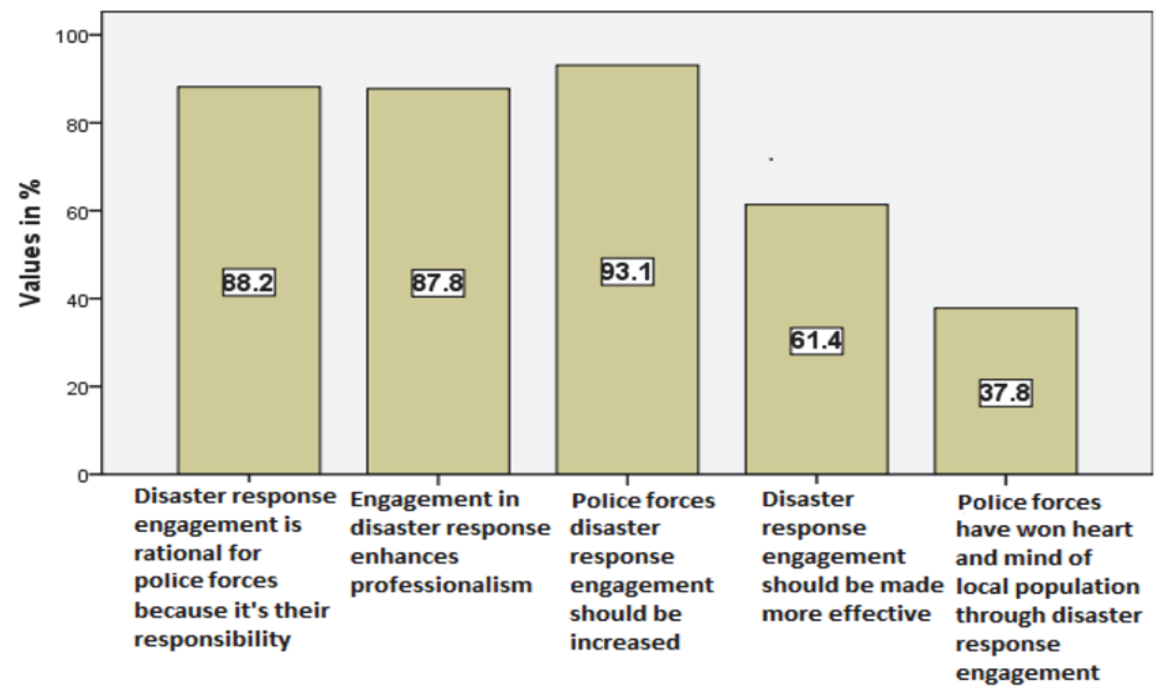

Figure 4. Perception on disaster response engagement

\subsection{Disaster Response Preparedness}

The result shows that the disaster response preparedness activities of the participants is not approving (see figure 5). Only $34 \%$ of the participants replied that they have taken some sort of disaster response training in their career. And only $24 \%$ of the participants responded that they have somehow rehearsing disaster response drills in their respective units. So over $66 \%$ of the participants are not trained and $76 \%$ are neither rehearsed. But $55 \%$ of the participants have replied that they have partaken in some kind of disaster response exercise in their units. Hence, in total, $44 \%$ of the study participants were found not engaged in any kind of preparedness activities in their career. But if we look at the engagement rate it's too high. $86 \%$ of the participants have replied that they have somehow engaged in disaster response operations in their career. Whereas the both trained and rehearsed percentage is below $34 \%$ (see figure 6). In that sense, this result reveals the larger tendency of using unprepared police personnel in disaster response operations which is empirically enough to raise the question in the effectiveness of such responses.

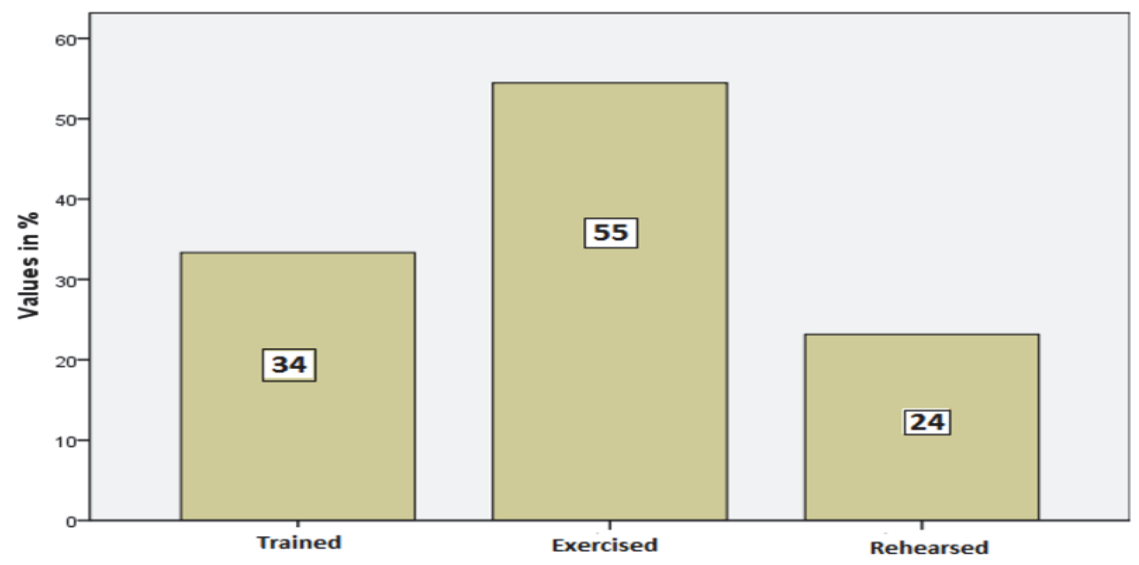

Figure 5. Involvement in disaster response preparedness 


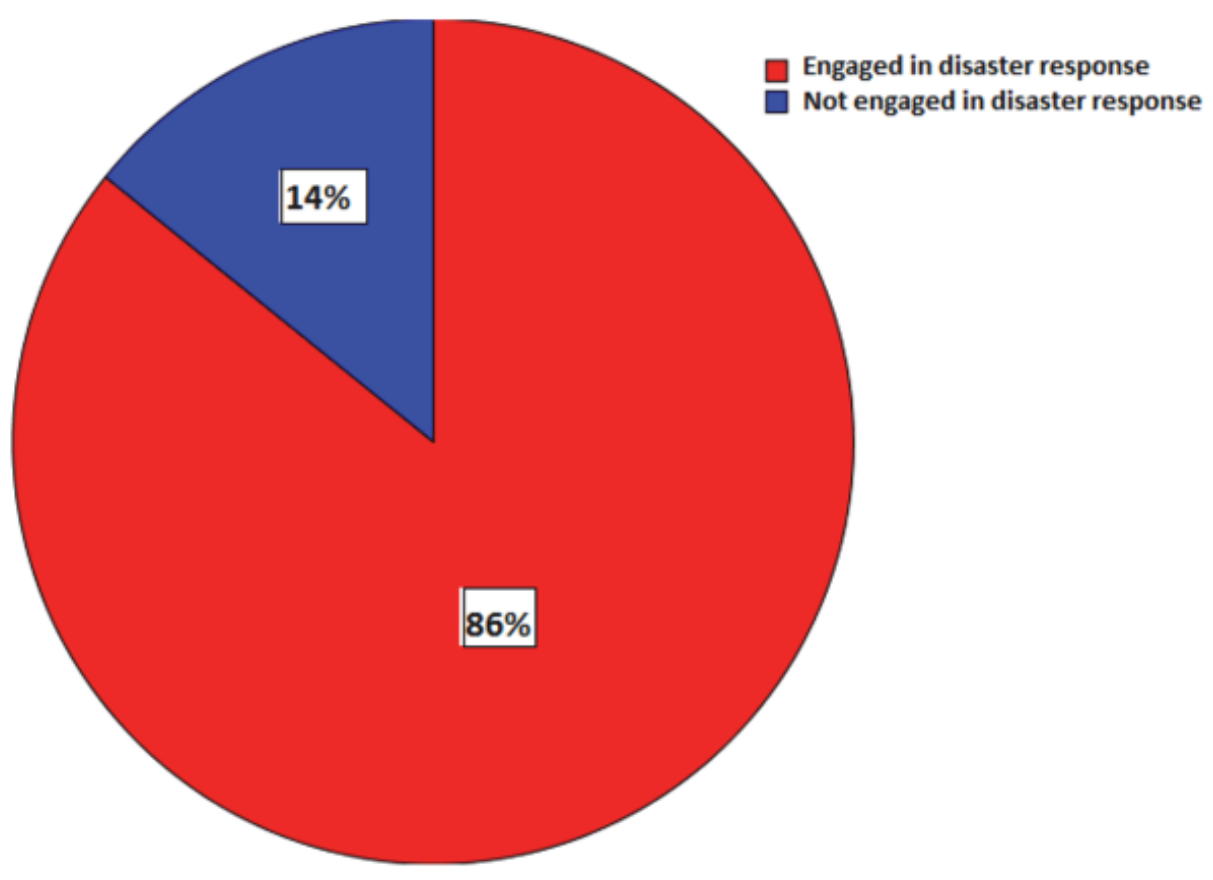

Figure 6. Engagement in disaster response

\subsection{Comparative Study of Two Police Forces}

The result of the analysis reveals that there is no significant difference in the disaster management fundamental knowledge and disaster response technical awareness amongst NP and APF study participants (see figure 7 \& 8). In the part of perception, the APF participants' result is marginally higher (see figure 9). But in preparedness activities there is a huge gap (see figure 10). The APF participants are more trained, exercised and rehearsed than the NP participants. In engagement as well, the APF participants are more engaged than the NP participants (see figure 11).

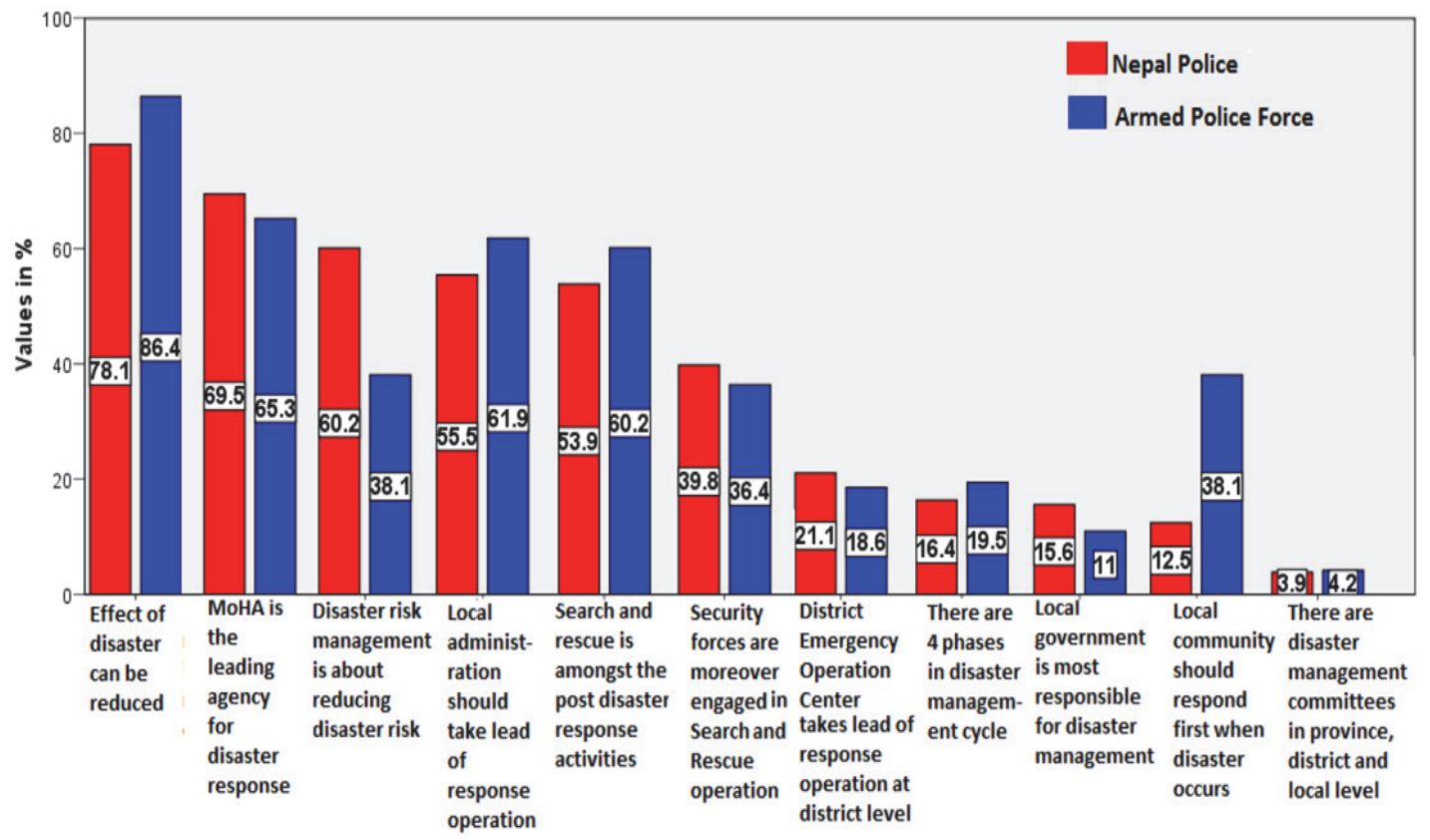

Figure 7. Fundamental disaster management knowledge of NP and APF 


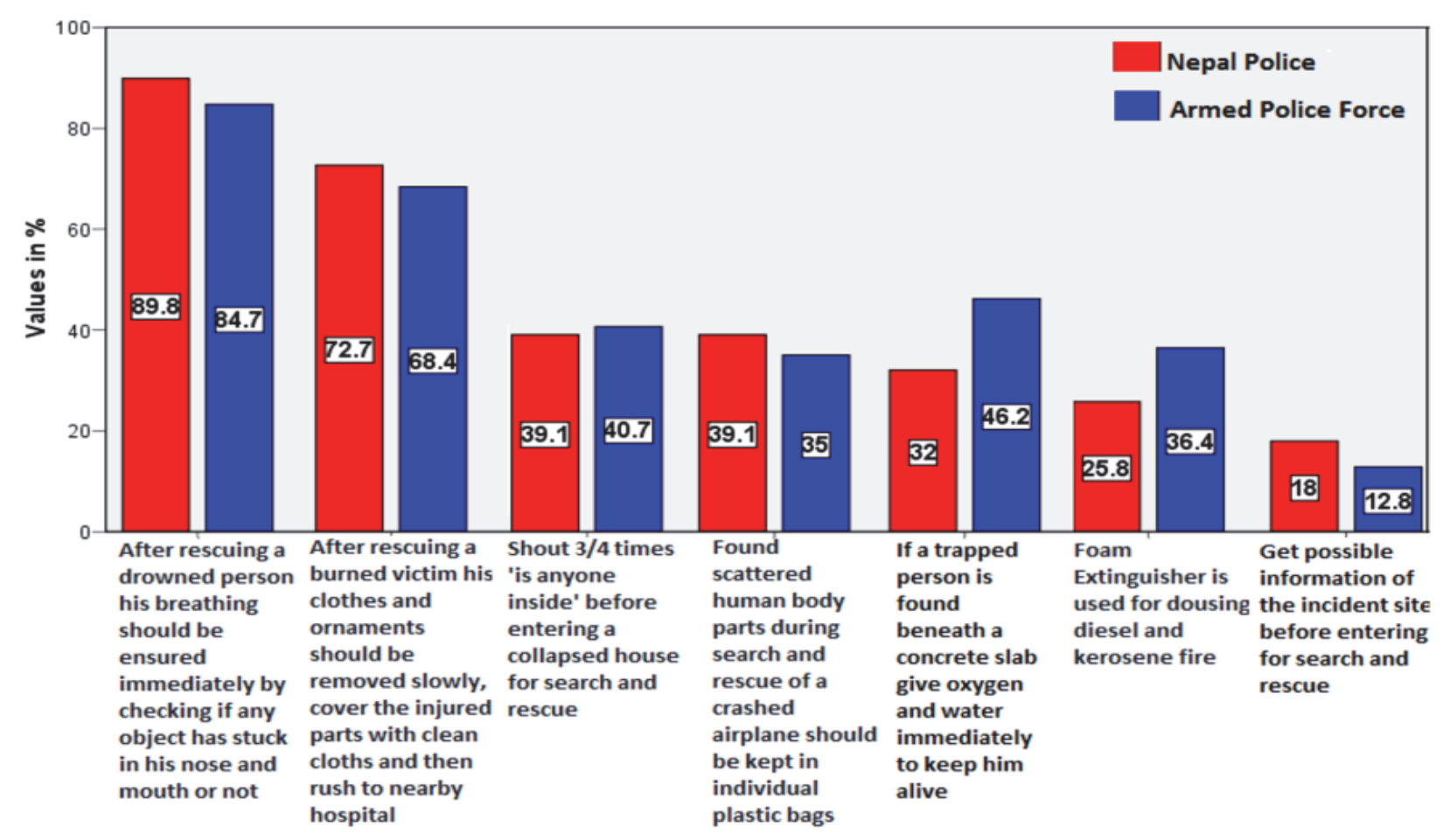

Figure 8. Technical disaster response knowledge of NP and APF

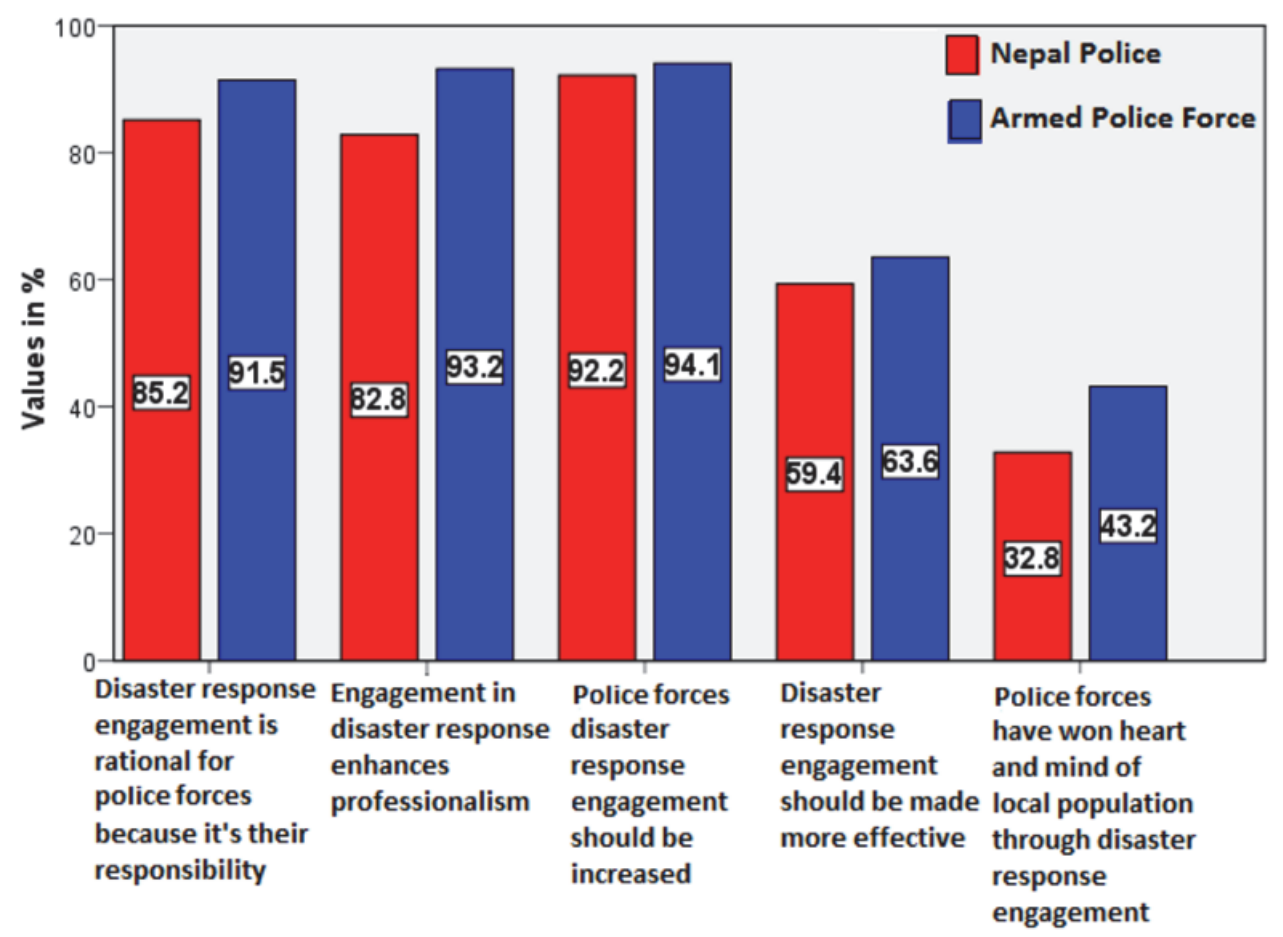

Figure 9. Disaster management engagement perception of NP and APF 


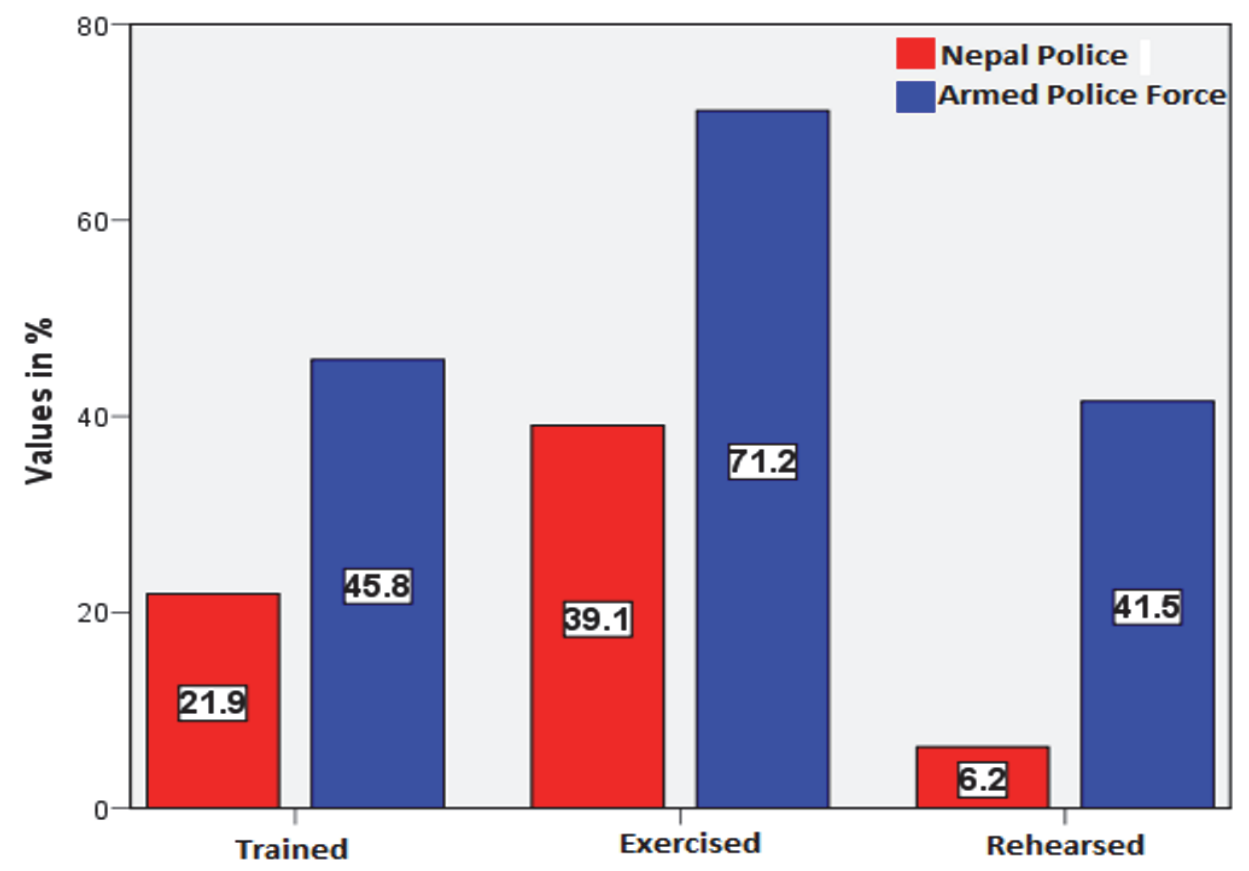

Figure 10. Preparedness activities of NP and APF

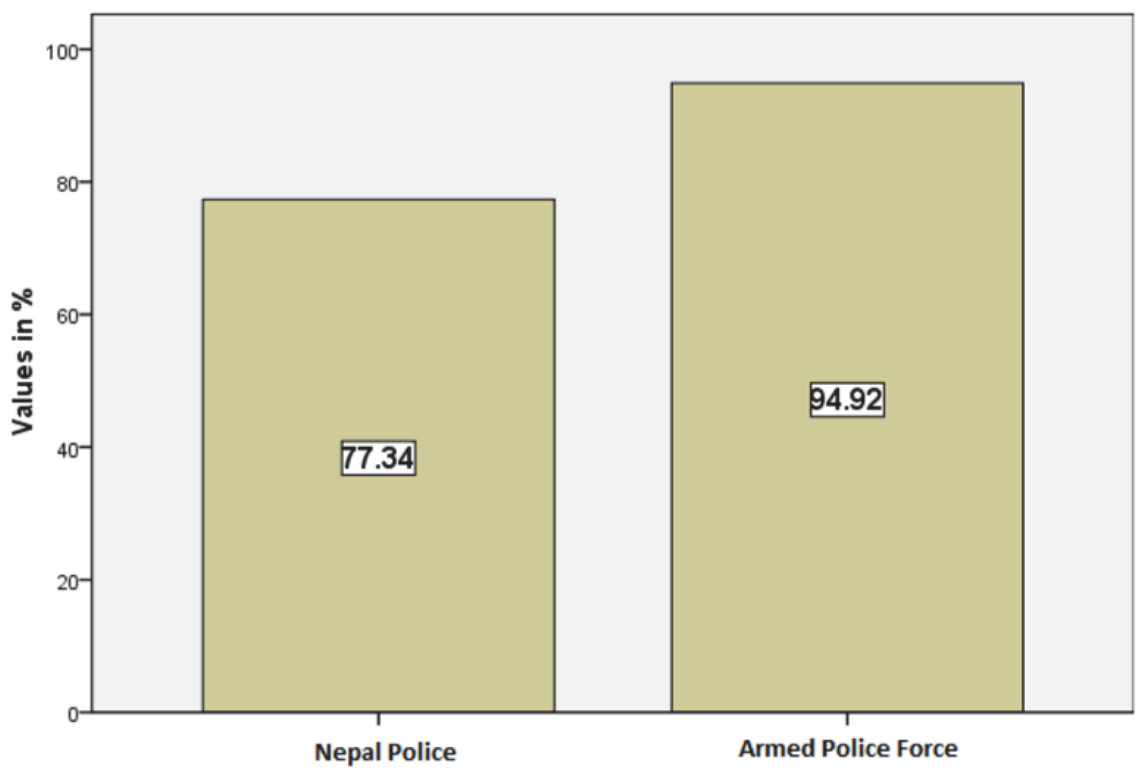

Figure 11. Engagement of NP and APF in disaster response

\subsection{Effect of Training and Rank in Competency}

Equation derived $(\mathrm{F}(3,241)=148.434, \mathrm{p}<0.000)$ from Linear Regression test justifies that the training factor is statistically significant to competency since $p$ value is less than 0.05 (see table 1 ). Whereas the individual $p$ values derived from the 'coefficients table' ensures only the training factor is statistically significant to preparedness (see table 2). Fundamental and technical knowledge do not have any statistical significant relation with training since their $\mathrm{p}$ values are over 0.05 .

Similarly, rank factor is also statistically significant to the competency as a whole $(F(3,242)=13.069, p<0.000)$ (see table 3). But as per the individual factor analysis, the rank is only statistically significant to the fundamental knowledge since $\mathrm{p}$ value is less than 0.5 . Technical knowledge and preparedness factors do not have statistical significant relation to the rank. (see table 4) 
Table 1. Statistical significance of training and competency

\begin{tabular}{lllllll}
\hline Model & Sum of Squares & df & Mean Square & F & Sig. \\
\hline \multirow{2}{*}{1} & Regression & 35.418 & 3 & 11.806 & 148.434 & $.000^{\mathrm{a}}$ \\
& Residual & 19.248 & 242 & .080 & & \\
& Total & 54.667 & 245 & & & \\
\hline
\end{tabular}

a. Predictors: (Constant), Preparedness, Technical Knowledge, Fundamental Knowledge

b. Dependent Variable: Training

Table 2. Statistical significance of training in knowledge and preparedness

\begin{tabular}{|c|c|c|c|c|c|c|}
\hline \multirow{2}{*}{ Model } & & \multicolumn{2}{|c|}{ Unstandardized Coefficients } & \multirow{2}{*}{$\begin{array}{l}\text { Standardized Coefficients } \\
\text { Beta }\end{array}$} & \multirow{2}{*}{$\mathbf{t}$} & \multirow{2}{*}{ Sig. } \\
\hline & & B & Std. Error & & & \\
\hline \multirow{4}{*}{1} & (Constant) & -.727 & .225 & & -3.235 & .001 \\
\hline & $\begin{array}{l}\text { Fundamental } \\
\text { Knowledge }\end{array}$ & .021 & .011 & .075 & 1.933 & .054 \\
\hline & Technical Knowledge & .024 & .013 & .073 & 1.873 & .062 \\
\hline & Preparedness & .360 & .018 & .785 & 20.488 & .000 \\
\hline
\end{tabular}

a. Dependent Variable: Training

Table 3. Statistical significance of rank in competency

\begin{tabular}{lllllll}
\hline \multicolumn{1}{l}{ Model } & Sum of Squares & df & Mean Square & F & 13.069 \\
\multirow{2}{*}{1} & Regression & 7.668 & 3 & 2.556 & $.000^{\mathrm{a}}$ \\
& Residual & 47.328 & 242 & .196 & \\
& Total & 54.996 & 245 & & \\
\hline
\end{tabular}

a. Predictors: (Constant), Preparedness, Technical Knowledge, Fundamental Knowledge

b. Dependent Variable: Rank.1

Table 4. Statistical significance of rank in knowledge and preparedness

\begin{tabular}{|c|c|c|c|c|c|c|}
\hline \multirow[t]{2}{*}{ Model } & & \multicolumn{2}{|c|}{$\begin{array}{l}\text { Unstandardized } \\
\text { Coefficients }\end{array}$} & \multirow{2}{*}{$\begin{array}{l}\text { Standardized Coefficients } \\
\text { Beta }\end{array}$} & \multirow[t]{2}{*}{$\mathbf{t}$} & \multirow[t]{2}{*}{ Sig. } \\
\hline & & B & Std. Error & & & \\
\hline \multirow{4}{*}{1} & (Constant) & 2.989 & .352 & & 8.488 & .000 \\
\hline & $\begin{array}{l}\text { Fundamental } \\
\text { Knowledge }\end{array}$ & -.101 & .017 & -.356 & -5.835 & .000 \\
\hline & Technical Knowledge & -.013 & .020 & -.038 & -.632 & .528 \\
\hline & Preparedness & .054 & .028 & .117 & 1.949 & .052 \\
\hline
\end{tabular}

a. Dependent Variable: Rank.1

\subsection{Correlation Analysis}

The Bivariate Correlation test signifies that the fundamental knowledge and technical knowledge are statistically correlated to each other since the $\mathrm{p}$ value is less than 0.05. But preparedness factor is neither correlated to fundamental knowledge nor to technical knowledge. In both the cases the p values are over 0.05 (see table 5).

Table 5. Correlations between fundamental knowledge, technical knowledge and preparedness

\begin{tabular}{lllll}
\hline & & Fundamental Knowledge & Preparedness & Technical Knowledge \\
\hline \multirow{3}{*}{ Fundamental Knowledge } & Pearson Correlation & 1 & .083 & $.195^{* *}$ \\
& Sig. (2-tailed) & & .194 & .002 \\
& $\mathrm{~N}$ & 246 & 246 & 246 \\
& Pearson Correlation & .083 & 1 & .070 \\
Preparedness & Sig. (2-tailed) & .194 & & .273 \\
& $\mathrm{~N}$ & 246 & 246 & 246 \\
\multirow{5}{*}{ Technical Knowledge } & Pearson Correlation & $.195^{* *}$ & .070 & 1 \\
& Sig. (2-tailed) & .002 & .273 & \\
& $\mathrm{~N}$ & 246 & 246 & 246 \\
\hline
\end{tabular}

**. Correlation is significant at the 0.01 level (2-tailed). 


\section{Discussions}

The results of the research have revealed that the competency of the ordinary troops of NP and APF is low. Their fundamental disaster management knowledge, technical knowledge and level of preparedness are deficient to meet the standard of effective response. This research has also attested another appalling fact that the use of disaster untrained police personnel in response operation in Nepal is high. Such employment does not only affect the response operation but also endangers both the lives of victim and responder.

Precisely such dearth of knowledge and preparedness entails the problem in command and control, communication, coordination, and efficiency and confidence of the responder. That ultimately delays, degrade or jeopardize the whole response effort. Similarly such deficiency is also an obstruction to the holistic effort where the different stakeholders have different task to carry out within limited timeframe, and the tasks are interrelated and interdependent. Thus it is imperative that the disaster management knowledge and preparedness of NP and APF personnel need to be maintained at the effective level.

This research has underscored another truth that the disaster response competency building initiatives for ordinary police personnel is in shadow in Nepal. That contradicts the national commitment towards the Hyogo and Sendai conferences (Koirala, 2014). The Priority Action 5 of Hyogo Framework and Priority Number 4 of Sendai Framework have particularly guided the government to enhance disaster response competency of the national institutions. Even the national periodic plans have also directed the government to meet this goal (National Planning Commission, 2013; National Planning Commission 2015). But the prevailing disaster specialized units focused response capacity building propensity of the organizations has garnered apathy towards investing resources and time for the ordinary troops' capacity building.

Tint et al. claimed that the disaster is a difficult and an abnormal scenario that demands high skilled responders with agile leadership, teamwork, risk taking capacity, calmness, and focused with good communication skills that is attainable through standard capacity building process such as training and rehearsal (Tint et al., 2015). Thus letting untrained troops respond to disaster situation is the sheer negligence and compromise. In that sense those troops that are supposed to be deployed in disaster should be trained properly. That demands the disaster response training mandatory for the ordinary troops of NP and APF. Slattery et al. described three types of training required for emergency responders- Individual, Collective and Leadership development trainings (Slattery et al., 2009). Individual training helps to establish, improve, and sustain individual proficiency. Collective training develops team work and focuses on enhancing group effort to complete a task whereas leadership development training empowers independent decision making potential which is much essential at the time of crisis and chaos (Slattery et al., 2009). Similarly, Nazli et al. stresses that the training should not be a one-time event (Nazli et al., 2014). Training should be followed by refresher courses, exercise and drills that helps to improve and upkeep the learned knowledge and skills for longer period.

On other hand the results of this investigation has helped to substantiate the fact that the quality and standard of the disaster response training in police forces is not of standard. The trained troops are lacking the basic fundamental and technical knowledge thus such trainings are far from meeting the goal set by the United Nations' International Search and Rescue Advisory Group (INSARAG). Similarly there is no regularity in rehearsal, exercise and drill which is not helping to materialize the gains of such trainings. It is imperative that there needs more effort to enhance the quality of such trainings and regularity and systematization of such preparedness curriculums. On boarding the national and international disaster training experts this deficiency can be sorted out.

Despite such gaps, the perception of the troops was found optimistic towards their engagement in disaster response operations. It is indeed encouraging since the members' perception plays leading role to achieve the aim of any organization (Nazli et al., 2014). Both the forces' ordinary troops believe that their disaster response engagement is rational, professional and encouraging. They also agree that their capacity is not sufficient to deliver effective response so needs to be enhanced. In such a conducive milieu the NP and APF shouldn't hesitate to invest more in their capacity building. It will work as the force multiplier to enhance the overall quality of the disaster response capacity of the organizations.

Despite this fact, heavy reliance on foreign aids, INGO and NGO for the disaster response capacity building is prevalent in police forces in Nepal. That is the most steadfast hurdle to upkeep the sustainability of the competency building process. Today UNDP, NSET, Red Cross Organization, WFP, etc are amongst the partner organizations rendering disaster response training in both the organizations. Jones et al. claimed that the organization's overreliance on external support for capacity building is problematic in the long run (Godfrey et al., 2002). Such tendency weakens the institutional ownership, limits institutional commitment, deepens dependency, and ultimately affects the institutional capacity (Godfrey et al., 2002). Therefore, the institutional capacity need to be 
strengthen through national investment. Flow of regular budget for disaster response capacity building process is the prime need in police forces at the moment. Eventually, there needs a common platform for comprehensive discourse and dialogue amongst the government authorities, the leaderships of the police forces, and disaster experts on 'how to systematize the disaster response competency building process in the police organizations'. Concurrently further academic research is also imperative in this context.

\section{Conclusion}

Indeed, the prevailing disaster response competency of NP and APF ordinary troops is not sufficient to carry out an effective response. The prevailing limited fundamental knowledge, technical knowledge, and preparedness activity have limited their capacity along with risked their lives and the lives of the victims.

There is an urgent need in Nepalese police forces that the focus should be shifted to enhance the disaster response capacity of such ordinary troops deployed at the local level. For the purpose, at first, the widespread reliance on foreign aid, NGO and INGO should be slash down ensuring regular national investment in capacity building process. Secondly, the development of a standard curriculum to ensures standard disaster response training is also imperative. Along with the exercise, drills and regular rehearsal are also another indispensable factors to maintain robust preparedness and that should be ensured in the local units focusing their ordinary troops. And lastly, these preparedness activities should be supported by the institutional policy that ensures the comprehensive involvement of ordinary troops in disaster response capacity building process. This will not only help to reduce the prevailing tendency of using untrained troops in disaster response but also ensures the effectiveness of the response operations conducted during disaster in the country.

\section{Acknowledgements}

This research was conducted with the extensive assistance from the officials of Himalayan Conservation Group, and the Ministry of Home Affairs. The support and kind participation of the officials from NP and APF in data collection and interview has made this work successful. Similarly, the guidance and assistance from subject matter experts, stakeholders and intellectual personalities working in disaster management venture was also invaluable to materialize this research. We extend our sincere gratitude to all these helping hands.

\section{References}

Anderson, W. (2006). This isn't representative of our department: Lessons from Hurricane Katrina for police disaster response planning. Retrieve from https://www.law.berkeley.edu/library/resources/disasters/Anderson.pdf

Arya, A. S. (1993). Training and Drills for General Public in Emergency Response to a Major Earthquake. Training and Education for Improving Earthquake Disaster Management in Developing Countries. UNCRD Meeting Reports Series, 57, 103-114.

Barelli R., Gulli, A., \& Norris, E. (2014). Soft skills in disaster preparedness and relief: A new approach to safety for non health care rescue teams. AnEur-Opa 2014-15 Project. Retrieved from http://www.cemecsanmarino.eu/doc/SoftSkillsDisasterReliefDraft-6.pdf

Bird, M., Cowie, S., Hawkes, A., Horton, B., Macgregor, C., Ong, J. E., ...Yasin, Z. (2007). Indian ocean tsunamis: environmental and socio-economical impacts in Langkawi, Malaysia, The Geographical Journal, 173(2), 103-117. https://doi.org/10.1111/j.1475-4959.2007.00224.x

Bonkiewicz, L., \& Ruback, R.B. (2012). The role of the police in evacuations: Responding to the social impact of a disaster. Police Quarterly, 15(2), 137-156. https://doi.org/10.1177/1098611112442808

Brancato, G., Macchia, S., Murgia, M., Simeoni, G., Blanke, K., Korner, T... Zlotnik, J. H. P. H. (2004). Handbook of recommended practices for Qquestionnaire development and testing in the European Statistical System.

Chhetri, M. B. P. (1999). Nepal Country Report. Ministry of Home Affairs (MoHA), Kathmandu.

Descy, P., \& Tessaring, M. (2002). Training and learning for competence.Second report on vocational training and research in Europe: executive summary (pp.3-43). Luxembourg: Office for Official Publications of the European Communities.

Disaster Risk Reduction and Management Act 2017. (2017, November 21). Retrieved from https://www.ilo.org/dyn/natlex/docs/ELECTRONIC/106076/129931/F1996604288/NPL106076\%20Npl.pdf

Drabek, T., \& Hoetmer, G. (1991). Emergency Management: Principles and Practice for Local Government. Washington, DC: International City County Management Association.

Drabek, T. E. (1985). Managing the emergency response. Public Administration Review, 45, 85-92. 
https://doi.org/10.2307/3135002

Efron, R. (1969). What is Perception? In R. S. Cohen \& M.W. Wartofsky (Eds.), Proceedings of the Boston Colloquium for the Philosophy of Science 1966/1968 (Vol. 4, p.137). Dordrecht, Holland: Reidel Publishing Company. https://doi.org/10.1007/978-94-010-3378-7_4

Gillespie, D., \& Colignon, R. (1993). Structural change in disaster preparedness network. International Journal of Mass Emergencies and Disasters, 11(2), 143-162.

Godfrey, M., Sophal, C., Kato, T., Piseth, L.V., Dorina, P., Saravy, T., Savora, T., \& Sovannarith, S. (2002). Technical assistance and capacity development in an aid-dependent economy: the experience of Combodia. World Development, 30(3), 355-373. https://doi.org/10.1016/S0305-750X(01)00121-8

Grunewald, F., \& Burlet, A. (2016). Nepal earthquake: A rapid review of the response and a few lessons learnt. Retrieved from https://www.urd.org/IMG/pdf/Lessons_learnt_and_areas_to_be_improved_in_Nepal_response.pdf

Heide, E. A. D. (1989). Disaster Response: Principles of Preparation and Coordination. St. Louis, Missouri: The C.V. Mosby Company.

Ingrassia, P. L., Foletti, M., Djalali, A., Scarone, P., Ragazzoni, L., Corte, F. D., \& Fisher, P. (2014). Education and training initiatives for crisis management in the European Union: a web based analysis of available programs. Prehospital and Disaster Medicine, 29(4), 115-126. https://doi.org/10.1017/S1049023X14000235

Jones, S., Oven, K. J., Manyena, B., \& Aryal, K. (2014). Governance Struggles and policy processes in disaster risk reduction: A case study from Nepal. Geoforum, 57, 78-90. https://doi.org/10.1016/j.geoforum.2014.07.011

Knoblich, G., \& Sebanz, N. (2006). The social nature of perception and action. Current Directions in Psychological Science, 15(3), 99. https://doi.org/10.1111/j.0963-7214.2006.00415.x

Koirala, P. K. (2014). Disaster management institution and system in Nepal. Kathmandu, Nepal: Ministry of Home Affairs.

Kuroiwa, J. A. (1993). Peru's national educational program for disaster prevention and mitigation (PNEPDPM). Training and education for improving earthquake disaster management in developing countries. UNCRD Meeting Report Series, 57, 95-102.

Mendis, D. S. K., Karunananda, A. S., Samaratunga, U., \& Ratnayake, U. (2007). An approach to the development of commonsense knowledge modeling system for disaster management. The Artificial Intelligence Review, 28(2), 179-196. https://doi.org/10.1007/s10462-009-9097-6

MoHA \& DPNet-Nepal. (2015). Nepal Disaster Report 2015. Ministry of Home Affairs (MoHA) and Disaster Preparedness Network Nepal (DPNet-Nepal), Kathmandu.

MoHA. (2016). Gorkha Earthquake -2015: Experience and learning. Kathmandu, Nepal: Ministry of Home Affairs, Disaster Management Department.

National Planning Commission. (2013). An approach paper to the thirteenth plan (Fy 2013/14 - 2015/16). Kathmandu, Nepal: Government of Nepal. Retrieved from http://extwprlegs1.fao.org/docs/pdf/nep150783.pdf

National Planning Commission. (2015). Fourteenth Plan: Fiscal Year 2016-17 to 2018-19. Kathmandu, Nepal: Government of Nepal. Retrieved from https:/www.npc.gov.np/images/category/14th-plan-full-document.pdf

Nazli, N. N. N. N., Sipon, S., \& Radzi, H. M. (2014). Analysis of training needs in disaster preparedness. ProcediaSocial and Behavioral Sciences, 140, 576-580. https://doi.org/10.1016/j.sbspro.2014.04.473

Nepal Police. (2016). Disaster Management Division SOP. Kathmandu, Nepal: Nepal Police Headquarters.

Penrose, J. M. (2000). The role of perception in crisis management. Public Relations Review, 26(2), 155-171. https://doi.org/10.1016/S0363-8111(00)00038-2

Pine, T. (1996). Integrated emergency management: Hierarchy or network? In T. Horlick-Jones, A. Amendola \& R. Casale (Eds.), Natural risk and civil protection (pp.494-506). London, UK:E \&FN Spon.

Poul, B. K. (2019). Channeling disaster aid: Process and problems. Disaster Relief Aid: Changes and Challenge (p.44).Cham, Switzerland: Palgrave Macmillan. https://doi.org/10.1007/978-3-319-77282-0

Quartelli, E. L., \& Dynes, R. R. (1977). Response to Social Crisis and Disaster. Annual Review of Sociology, 3, 23-49. https://doi.org/10.1146/annurev.so.03.080177.000323 
Ronan, K., Crellin, K., \& Johnston, D. (2010). Correlates of hazards education for youth: a replication study. Nat Hazards, 53(3), 503-26. https://doi.org/10.1007/s11069-009-9444-6

Slattery, C., Syvertson, R., \& Jr, S. K. (2009). The eight step training model: Improving disaster management leadership. Journal of Homeland Security and Emergency Management, 6(1), 1. https://doi.org/10.2202/1547-7355.1403

Subedi, S. (2013). Armed Police Force in Disaster Management. Kathmandu, Nepal: Army Command and Staff College.

Tanaka, K. (1996). The Kobe earthquake: The system response. A disaster report from Japan. European Journal of Emergency Medicine, 3, 263-269. https://doi.org/10.1097/00063110-199612000-00009

Tint, B.S., Waters, V. M., \& Driel, R. V. (2015). Games for learning and dialogue on humanitarian logistics applied improvisation training for disaster readiness and response: Preparing humanitarian workers and communities for the unexpected. Journal of Humanitarian Logistics and Supply Chain Management, 5(1), 73-94. https://doi.org/10.1108/JHLSCM-12-2013-0043

Twigg, J., \& Mosel, I. (2017). Emergent groups and spontaneous volunteers in urban disaster response. International Institute for Environment and Development, 29(2), 443-458. https://doi.org/10.1177/0956247817721413

Varano, S. P., \& Schafer, J. A. (2012). Policing Disasters: The role of Police in the Pre-Disaster Planning and PostDisaster Responses. Sociology of Crime, Law and Deviance, 17, 83-112. https://doi.org/10.1108/S15216136(2012)0000017008

Wolf, J., \& Moser, S. C. (2011). Individual understandings, perception, and engagement with climate change: insights from in-depth studies across the world. Advanced Review, 2, 547-569. https://doi.org/10.1002/wcc. 120

Yasuda, T., Takayama, Y., \& Soma, K. (2014). Activities of Japanese police in the Great East Japan Earthquake. Journal of International Criminal Justice Research, 1, 1-18. https://doi.org/10.1596/978-1-4648-0153-2_ov

Zhou, L., Pereera, S., Jayawickrama, J., \& Adeniyi, O. (2014). The Implementation of Hyogo Framework for Action for disaster resilience education. Procedia Economics and Finance, 18, 576-583. https://doi.org/10.1016/S2212-5671(14)00978-2

\section{Copyrights}

Copyright for this article is retained by the author(s), with first publication rights granted to the journal.

This is an open-access article distributed under the terms and conditions of the Creative Commons Attribution license (http://creativecommons.org/licenses/by/4.0/). 